\title{
Geobacter bemidjiensis sp. nov. and Geobacter psychrophilus sp. nov., two novel Fe(III)-reducing subsurface isolates
}

Correspondence
Kelly P. Nevin
knevin@microbio.umass.edu

\section{INTRODUCTION}

$\mathrm{Fe}(\mathrm{III})$ is an abundant electron acceptor in subsurface environments (Lovley, 1991). A wide variety of bacteria and archaea are able to couple the oxidation of organic matter to the reduction of $\mathrm{Fe}(\mathrm{III})$ minerals (Lovley et al., 2004). The temperature at which micro-organisms are known to reduce $\mathrm{Fe}$ (III) ranges from 4 to $121^{\circ} \mathrm{C}$ (Finneran et al., 2003; Kashefi \& Lovley, 2003; Holmes et al., 2004c; Lovley et al., 2004). Most previously described Fe(III)-reducing microorganisms grow fastest at temperatures in the range

Abbreviations: AQDS, anthraquinone 2,6-disulfonate; NTA, nitrilotriacetate.

The GenBank/EMBL/DDBJ accession numbers for the 16S rRNA, gyrB, fus $A$, nifD, rpoB and recA gene sequences of strain $B^{\top}{ }^{\top}$ are AY187307, AY547335, AY188890, AY186994, AY186914 and AY186883 and those for the 16S rRNA, fusA and nifD gene sequences of strain $\mathrm{P}_{35}^{\top}$ are AY653548, AY653550 and AY795909.

Similarity matrices for $16 \mathrm{~S}$ rRNA and nifD gene sequences of the novel isolates and related strains are available as supplementary material in IJSEM Online.
20-30 ${ }^{\circ} \mathrm{C}$ (Lovley et al., 2004), and a number of Fe(III)reducing hyperthermophiles and thermophiles have been described (Vargas et al., 1998; Kashefi et al., 2004). However, only two $\mathrm{Fe}(\mathrm{III})$-reducing bacteria have been show to grow with $\mathrm{Fe}(\mathrm{III})$ as electron acceptor at $4{ }^{\circ} \mathrm{C}$ in pure culture, Rhodoferax ferrireducens, a freshwater facultative organism capable of reducing soluble, chelated iron(III) nitrilotriacetate (NTA) (Finneran et al., 2003), and Geopsychrobacter electrodiphilus, a marine anaerobe capable of amorphous iron(III) oxide reduction (Holmes et al., 2004c). Geopsychrobacter species are members of the family Geobacteraceae, the largest group of $\mathrm{Fe}(\mathrm{III})$-reducing bacteria, within the 'Deltaproteobacteria' (Lovley et al., 2004). Members of this family have many distinguishing characteristics other than their ability to reduce $\mathrm{Fe}(\mathrm{III})$, among them nitrogen fixation and the ability to oxidize acetate and other multi-carbon organic substrates to carbon dioxide (Bazylinski et al., 2000; Coppi et al., 2001; Holmes et al., 2004b; Lovley et al., 2004).

Members of the family Geobacteraceae also play an 
important role in the in-situ bioremediation of uraniumcontaminated aquifers (Anderson et al., 2003; Istok et al., 2004; Vrionis et al., 2005) and in other contaminated subsurface environments, including aquifers contaminated with petroleum (Rooney-Varga et al., 1999; SnoeyenbosWest et al., 2000) or landfill leachate (Roling et al., 2001) as well as lake sediments contaminated with heavy metals (Cummings et al., 2003). Geobacter species are also found in a wide variety of pristine environments (Snoeyenbos-West et al., 2000; Stein et al., 2001; Ikenaga et al., 2003; Petrie et al., 2003; Helms et al., 2004; Holmes et al., 2004a). One reason for this is that members of the Geobacteraceae can oxidize acetate, which is the primary intermediate in the anaerobic degradation of organic matter in sedimentary systems (Lovley \& Chapelle, 1995). Furthermore, members of the Geobacteraceae have a highly effective strategy for localizing iron(III) oxides and directly transferring electrons to the iron(III) oxide surface (Nevin \& Lovley, 2000a, 2002a, b; Childers et al., 2002).

Despite the environmental significance of dissimilatory $\mathrm{Fe}$ (III) reduction and the important role that Geobacter species play in $\mathrm{Fe}(\mathrm{III})$ reduction in the environment, relatively few Geobacter species have been fully characterized. The purpose of this study was to recover organisms with $16 \mathrm{~S}$ rRNA gene sequences similar to those that predominate in subsurface environments, in which $\mathrm{Fe}$ (III) reduction is important, in order to understand better the role that these organisms play in $\mathrm{Fe}$ (III) reduction. Here we describe three isolates from a site in Massachusetts and an isolate from a site in Minnesota; all four isolates are members of Geobacter.

\section{METHODS}

Enrichment and isolation. Strict anaerobic techniques for the culturing of $\mathrm{Fe}$ (III)-reducing micro-organisms (Lovley, 2000, 2005) were used throughout. Sediment was collected as previously described from the background section of an aquifer in Bemidji, MN, USA, as part of ongoing research to study $\mathrm{Fe}$ (III) reduction and aromatic hydrocarbon oxidation in the subsurface (Anderson \& Lovley, 1999, 2000). Sediment was transferred to the laboratory, incubated under anoxic conditions and amended with $5 \mathrm{mM}$ acetate and $100 \mu \mathrm{M}$ anthraquinone 2,6-disulfonate (AQDS) to promote $\mathrm{Fe}$ (III) reduction in the sediments, as described previously (Nevin \& Lovley, $2000 \mathrm{~b}$ ). Once active $\mathrm{Fe}(\mathrm{III})$ reduction had been established, sediments were serially diluted in a bicarbonate-buffered freshwater medium (Lovley \& Phillips, 1988) with acetate $(20 \mathrm{mM})$ as the electron donor and poorly crystalline iron(III) oxide $\left(100 \mathrm{mmol}^{-1}\right)$ as the electron acceptor. The $10^{-3}$ dilution, which actively reduced $\mathrm{Fe}$ (III), was transferred (10\% inoculum) into fresh medium three times and then streaked onto basal salts solid plate medium with fumarate $(40 \mathrm{mM})$ as the electron acceptor and acetate $(20 \mathrm{mM})$ as the electron donor. The isolate was obtained from a single colony and grown up in basal salts liquid medium before transfer to iron(III) citrate media for further characterization.

The Plymouth isolates (strains P11, P35 ${ }^{\mathrm{T}}$ and P39) were obtained from groundwater from a highway runoff recharge pool located adjacent to State Route 25 (SR25) in Plymouth, MA, USA. The pool was constructed to collect runoff generated by SR25, which opened in August 1987 (Church et al., 1996). The Massachusetts Department of Environmental Protection enacted restrictions on this area requiring the use of non-chloride de-icing agents along a $1900 \mathrm{~m}$ section of highway impacting nearby cranberry bogs. Since opening, the primary road de-icing agent used on this stretch of highway has been calcium magnesium acetate (CMA). The unconfined aquifer underlying the study site is part of the Wareham Outwash Plain, consisting of fineto coarse-grained sand. The concentration of acetate in the groundwater varies between 0 and $5 \mathrm{mM}$ (Ostendorf, 1997-2004). This site serves as an analogue for the microbiology likely to be found in extended long-term acetate injection into the subsurface for in-situ uranium bioremediation. Groundwater $(1 \mathrm{ml})$ was added to the same acetate-iron(III) oxide medium described above. After 15 consecutive transfers (10\% inoculum), roll tubes containing iron(III) oxide and acetate were made. Colonies were picked anaerobically from roll tubes with a bent Pasteur pipette and placed in $2 \mathrm{ml}$ of the same liquid medium.

Light and electron microscopy. Cells were routinely examined by phase-contrast microscopy. Electron microscopy was done in the microscopy facility at the University of Massachusetts, Amherst.

Characterization of anaerobic growth and electron donor and acceptor utilization. Strain $\mathrm{Bem}^{\mathrm{T}}$ was incubated at $30{ }^{\circ} \mathrm{C}$ and strains P11, P35 ${ }^{\mathrm{T}}$ and P39 were incubated at $17^{\circ} \mathrm{C}$ for all growth and donor/acceptor utilization experiments. Acetate $(10 \mathrm{mM})$ was the electron donor for all evaluations of electron acceptor utilization. For electron donor utilization experiments, iron(III) citrate $(55 \mathrm{mM})$ was the electron acceptor for the studies with strain Bem ${ }^{\mathrm{T}}$ and iron(III) oxide $(100 \mathrm{mM})$ was the acceptor for studies with strains P11, P35 ${ }^{\mathrm{T}}$ and P39. Iron(III) oxide reduction was monitored as production of magnetite (Lovley et al., 1987); all other electron acceptors were determined visually by observing precipitation [iron(III) citrate, iron(III) pyrophosphate and iron(III) NTA], colour change [AQDS, iron(III) citrate, iron(III) pyrophosphate, iron(III) NTA and manganese(IV) oxide] or increase in optical density (fumarate, nitrate and malate). A graphite electrode serving as the sole electron acceptor was evaluated in an anoxic dual-chambered fuel cell as described previously (Bond et al., 2002; Bond \& Lovley, 2003).

Temperature, $\mathbf{p H}$ and salt tolerance. Temperature and $\mathrm{pH}$ tests for strain $\mathrm{Bem}^{\mathrm{T}}$ were performed in media containing iron(III) citrate $(55 \mathrm{mM})$ and acetate $(10 \mathrm{mM})$.

Strains P11, P35 ${ }^{\mathrm{T}}$ and $\mathrm{P} 39$ were tested for temperature, $\mathrm{pH}$ and salt tolerance in media containing iron(III) oxide $\left(100 \mathrm{mmol}^{-1}\right)$ and acetate $(10 \mathrm{mM})$. Strains $\mathrm{P} 11, \mathrm{P} 35^{\mathrm{T}}$ and P39 were also tested for growth in media containing salt concentrations ranging from 10 to $50 \mathrm{~g} \mathrm{NaCl}^{-1}$. Salt tolerance was also tested by transferring cells back to medium containing no $\mathrm{NaCl}$ after two exposures to these various $\mathrm{NaCl}$ concentrations. $\mathrm{Fe}(\mathrm{II})$ was assayed with ferrozine as described previously (Lovley \& Phillips, 1987).

Cytochrome content, G+C content and DNA-DNA hybridization. Cytochrome analysis was performed on the four isolates and Geobacter metallireducens using cells grown in either iron(III) citrate or iron(III) oxide medium. Oxalate was used to dissolve $\mathrm{Fe}(\mathrm{II})$ (Lovley \& Phillips, 1986). Three millilitres of culture was resuspended in $20 \mathrm{mM}$ pH 7 PIPES/NaOH and spectra were obtained as described previously (Caccavo et al., 1994) on a Shimadzu UV2401-PC dual-beam spectrophotometer. G+C content and DNA-DNA hybridization analyses (Cashion et al., 1977; De Ley et al., 1970; Huß et al., 1983) were performed by the Identification Service of the Deutsche Sammlung von Mikroorganismen und Zellkulturen.

DNA extraction and PCR amplification of 165 rRNA and nifD genes. Cells $(10 \mathrm{ml})$ were collected by centrifugation and genomic DNA was extracted using the BIO 101 FastDNA Spin kit following the manufacturer's instructions. 
16S rRNA gene sequences for strains $\mathrm{P} 35^{\mathrm{T}}, \mathrm{P} 11, \mathrm{P} 39$ and $\mathrm{Bem}^{\mathrm{T}}$ were amplified with primers 8 forward (Eden et al., 1991) and 1492 reverse (Amann et al., 1990; Achenbach \& Woese, 1995) as described previously (Holmes et al., 2004b). Gene fragments from the nifD genes in strains $\mathrm{P} 35^{\mathrm{T}}$ and $\mathrm{Bem}^{\mathrm{T}}$ were amplified with primers NIFD883F/ NIFD1337R (Ueda et al., 1995) as described previously (Holmes et al., 2004b). PCR products were purified from agarose gel with the QIAquick gel extraction kit (Qiagen) and ligated into the TOPO TA cloning kit, version K2 (Invitrogen) according to the manufacturers' instructions. Plasmid inserts were then amplified with M13 forward and reverse primers (Invitrogen) and PCR products were prepared for sequencing with a Qiaquick PCR purification kit (Qiagen).

Phylogenetic analysis of strains $\mathbf{P 3 5}^{\mathbf{T}}$, P39, P11 and Bem ${ }^{\top}$. The $16 \mathrm{~S}$ rRNA and nifD gene fragments from strains $\mathrm{P} 35^{\mathrm{T}}, \mathrm{P} 11$, $\mathrm{P} 39$ and $\mathrm{Bem}^{\mathrm{T}}$ were compared to the GenBank nucleotide and protein databases using the BLASTN and BLASTX algorithms (Altschul et al., 1990). Nucleotide and amino acid sequences were manually aligned in the Genetic Computer Group (GCG) sequence editor (Wisconsin Package version 10). Aligned sequences were imported into PAUP 4.0b 4a (Swofford, 1998), where phylogenetic trees were inferred. Identical branching orders were observed with maximumparsimony, maximum-likelihood and distance-based algorithms when 16S rRNA gene sequences were compared (not shown). Similar branching orders were obtained with these three algorithms when nifD gene sequences were compared (not shown). Bootstrap values were calculated by all three analyses and 1280 and 456 nucleotide positions, respectively, were considered for $16 \mathrm{~S}$ rRNA and nifD gene comparisons.

The similarity matrix program (Maidak et al., 2001) available on the Ribosomal Database Project II website, LFASTA version 3.2 (Pearson, 1990) and CLUSTAL W (Thompson et al., 1997) were used to generate similarity matrices considering 1280 nucleotides from the $16 \mathrm{~S}$ rRNA gene and 151 amino acid positions from the translation product of the nifD gene fragment.

\section{RESULTS AND DISCUSSION}

\section{Morphology}

Cells of strains Bem ${ }^{\mathrm{T}}, \mathrm{P} 11, \mathrm{P} 35^{\mathrm{T}}$ and $\mathrm{P} 39$ were rod-shaped, curved, Gram-negative, non-sporulating and slightly wrinkly (when viewed by electron microscopy) in appearance. Cells of strains P11, $\mathrm{P} 35^{\mathrm{T}}$ and $\mathrm{P} 39$ were approx. $2 \cdot 5-$ $3 \times 0 \cdot 8 \mu \mathrm{m}$ and were motile by means of a monotrichous flagellum two to three times the length of the cell (Fig. 1a). Cells of strain Bem ${ }^{\mathrm{T}}$ were approx. $2 \cdot 5-4 \times 0 \cdot 5 \mu \mathrm{m}$ and motility and flagella were not observed (Fig. 1b). Cells from all strains appeared as single cells or in chains of two to three cells. Strains P11, P35 $5^{\mathrm{T}}$ and P39 formed aggregates when growing on some electron acceptors, including iron(III) citrate and fumarate.

\section{Electron donors and acceptors utilized}

Compounds used by the strains as electron donors are indicated in Table 1 and those used as electron acceptors are indicated in Table 2.

\section{Temperature and $\mathrm{pH}$ and salt tolerance}

Strain Bem ${ }^{\mathrm{T}}$ grew fastest at $30^{\circ} \mathrm{C}$, but also grew at $15,20,25$, 30,32 and $37^{\circ} \mathrm{C}$. The $\mathrm{pH}$ for fastest growth of strain Bem ${ }^{\mathrm{T}}$

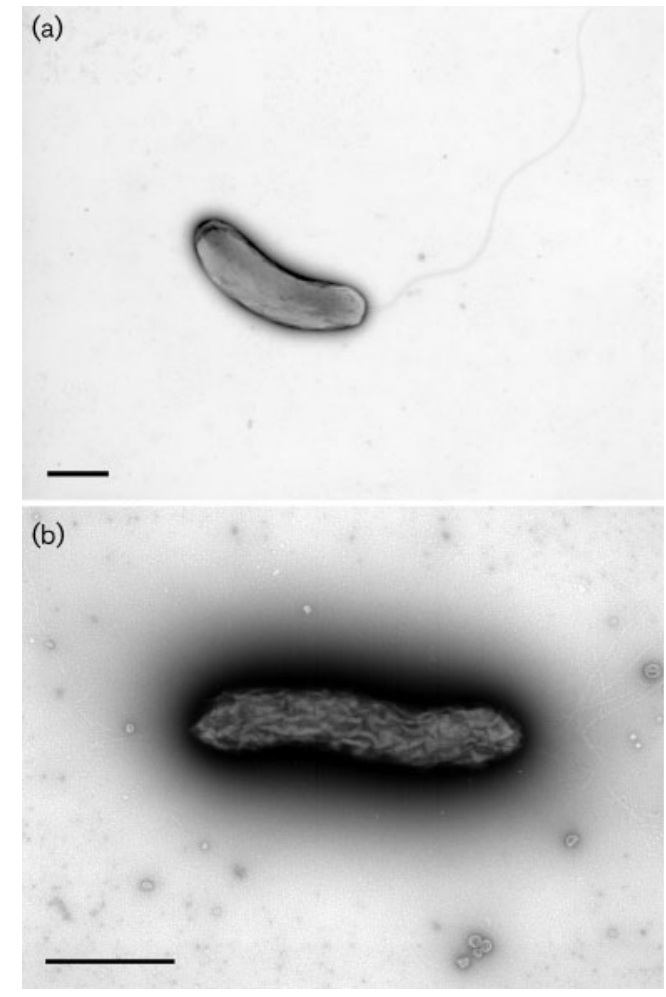

Fig. 1. (a) Transmission electron micrograph of strain $P 35^{\top}$ grown on medium with poorly crystalline iron(III) oxide $\left(100 \mathrm{mmol} \mathrm{I}^{-1}\right)$ provided as the electron acceptor and acetate $(10 \mathrm{mM})$ as the electron donor. (b) Scanning electron micrograph of a cell of strain $\mathrm{Bem}^{\top}$ grown on medium with iron(III) citrate $(50 \mathrm{mM})$ provided as the electron acceptor and acetate $(10 \mathrm{mM})$ as the electron donor. Bars, $1 \mu \mathrm{m}$.

was 7. The $\mathrm{pH}$ and temperature ranges of strain $\mathrm{Bem}^{\mathrm{T}}$ are typical of previously described Geobacter species (Lovley et al., 2004).

Strains P11, P35 ${ }^{\mathrm{T}}$ and P39 had a broad temperature growth range; similar growth rates were observed at 17,22 and $30^{\circ} \mathrm{C}$ (Fig. 2). They also grew at 4 and $10^{\circ} \mathrm{C}$, but not at $37^{\circ} \mathrm{C}$ (Fig. 2). No previously described Geobacter species are capable of growth at $4{ }^{\circ} \mathrm{C}$ (Lovley et al., 2004); however, other members of the family Geobacteraceae, the marine strains of Geopsychrobacter electrodiphilus, grow at $4{ }^{\circ} \mathrm{C}$ (Holmes et al., 2004c). Geopsychrobacter electrodiphilus and Rhodoferax ferrireducens are the only other bacteria that are known to grow at $4{ }^{\circ} \mathrm{C}$ while using $\mathrm{Fe}(\mathrm{III})$ as terminal electron acceptor. At $4{ }^{\circ} \mathrm{C}$, strains $\mathrm{P} 11, \mathrm{P} 35^{\mathrm{T}}$ and $\mathrm{P} 39$ reduce $\mathrm{Fe}$ (III) two to three times faster than has been reported for the other $\mathrm{Fe}(\mathrm{III})$-reducers capable of growth at this temperature (Finneran et al., 2003; Holmes et al., 2004c). Other iron(III)-citrate-reducing bacteria [Shewanella gelidimarina ACAM $456^{\mathrm{T}}$, Shewanella frigidimarina ACAM $591^{\mathrm{T}}$ (Bowman et al., 1997), Shewanella pealeana ANG$\mathrm{SQI1}^{\mathrm{T}}$ (Leonardo et al., 1999), Shewanella livingstonensis NF22 ${ }^{\mathrm{T}}$ (Bozal et al., 2002), Desulfofrigus oceanense ASv26 ${ }^{\mathrm{T}}$, 
Table 1. Growth of strains $\mathrm{Bem}^{\top}, \mathrm{P} 11, \mathrm{P} 35^{\top}$ and $\mathrm{P} 39$, Geobacter chapellei $172^{\top}$ and Geobacter bremensis Dfr1 ${ }^{\top}$ on various electron donors

Iron(III) citrate (strain $\mathrm{Bem}^{\mathrm{T}}$ ) or iron(III) oxide (strains P11, $\mathrm{P} 35^{\mathrm{T}}$ and P39) was provided as the electron acceptor. Data for reference species were taken from Coates et al. (1996, 2001) (Geobacter chapellei $172^{\mathrm{T}}$ ) and from Straub et al. (1998) and Straub \& Buchholz-Cleven (2001) (Geobacter bremensis Dfr ${ }^{\mathrm{T}}$ ). Acetate, ethanol and lactate (all at $10 \mathrm{mM}$ ) tested positive for all strains shown. The following were tested and proved negative for strains $\mathrm{Bem}^{\mathrm{T}}, \mathrm{P} 11, \mathrm{P} 35^{\mathrm{T}}$ and $\mathrm{P} 39$ : acetoin $\left(1 \mathrm{~g} \mathrm{l}^{-1}\right)$, arginine $(5 \mathrm{mM})$, caproate $(10 \mathrm{mM})$, Casamino acids $\left(1 \mathrm{~g} \mathrm{l}^{-1}\right)$, ferulate $(0.5 \mathrm{mM})$, fructose $(10 \mathrm{mM})$, gallic acid $\left(0.68 \mathrm{~g} \mathrm{l}^{-1}\right)$, glucose (5 mM), glycerol $(6 \mathrm{mM})$, mannitol $(10 \mathrm{mM})$, nicotinate $(0.5 \mathrm{mM})$, proline $(10 \mathrm{mM})$, serine $(10 \mathrm{mM})$ and syringate $(0.5 \mathrm{mM})$. The following were also tested and proved negative for strain $\mathrm{Bem}^{\mathrm{T}}$ : benzaldehyde $(0.5 \mathrm{mM})$, benzyl alcohol $(0.5 \mathrm{mM})$, glutamine $(10 \mathrm{mM})$, isopropanol $(10 \mathrm{mM})$, methanol $(20 \mathrm{mM})$, naphthalene $(0.5 \mathrm{mM}), o$-hydroxybenzoate $(0.5 \mathrm{mM}), \quad p$-hydroxybenzaldehyde $(0.5 \mathrm{mM}), p$-hydroxybenzoate $(0.5 \mathrm{mM}), p$-hydroxybenzyl alcohol $(0.5 \mathrm{mM})$, phenol $(0.5 \mathrm{mM})$, salicylic acid $(10 \mathrm{mM})$ and toluene $(1,5$ and $10 \mathrm{mM})$. NT, Not tested.

\begin{tabular}{|lcccccc|}
\hline Donor & Bem $^{\mathbf{T}}$ & P11 & P35 $^{\mathbf{T}}$ & P39 & $\mathbf{1 7 2}^{\mathbf{T}}$ & Dfri $^{\mathbf{T}}$ \\
\hline Benzoate $(2 \mathrm{mM})$ & + & - & - & - & - & + \\
Butanol $(10 \mathrm{mM})$ & + & + & + & + & $\mathrm{NT}$ & + \\
Butyrate $(10 \mathrm{mM})$ & + & - & - & - & $\mathrm{NT}$ & + \\
Formate $(10 \mathrm{mM})$ & - & + & + & + & + & + \\
Hydrogen $(130 \mathrm{kPa})^{*}$ & + & - & - & - & - & + \\
Isobutyrate $(10 \mathrm{mM})$ & + & - & - & - & $\mathrm{NT}$ & $\mathrm{NT}$ \\
Malate $(10 \mathrm{mM})$ & + & + & + & + & $\mathrm{NT}$ & + \\
Propionate $(10 \mathrm{mM})$ & + & - & - & - & - & + \\
Pyruvate $(10 \mathrm{mM})$ & + & + & + & + & $\mathrm{NT}$ & + \\
Succinate $(10 \mathrm{mM})$ & + & + & + & + & $\mathrm{NT}$ & + \\
Tryptone $\left(1 \mathrm{~g} \mathrm{l^{-1 }}\right)$ & - & + & - & - & $\mathrm{NT}$ & $\mathrm{NT}$ \\
Valerate $(10 \mathrm{mM})$ & + & - & - & - & $\mathrm{NT}$ & - \\
Yeast extract $\left(0 \cdot 5 \mathrm{~g} \mathrm{l}^{-1}\right)$ & - & - & - & + & $\mathrm{NT}$ & $\mathrm{NT}$ \\
\hline
\end{tabular}

*Acetate $(0 \cdot 1 \mathrm{mM})$ was provided as carbon source for growth on hydrogen.

Desulfofrigus fragile $\mathrm{LSv} 21^{\mathrm{T}}$, Desulfotalea psychrophila $\mathrm{Lsv}_{5}{ }^{\mathrm{T}}$ and Desulfotalea arctica LSv514 ${ }^{\mathrm{T}}$ (Knoblauch et al., 1999)] that are capable of growth at $4{ }^{\circ} \mathrm{C}$ were not tested for $\mathrm{Fe}(\mathrm{III})$ reduction at $4{ }^{\circ} \mathrm{C}$, nor are they able to reduce insoluble forms of $\mathrm{Fe}(\mathrm{III})$, which are the predominant forms of $\mathrm{Fe}(\mathrm{III})$ in most environments.

Strains P11, P35 ${ }^{\mathrm{T}}$ and P39 were capable of growth and magnetite production at $\mathrm{pH}$ values ranging from $6 \cdot 0$ to $9 \cdot 0$, with fastest growth at $\mathrm{pH} 7 \cdot 0$. No growth was observed at $\mathrm{pH} 5 \cdot 0$. The $\mathrm{pH}$ ranges of strains $\mathrm{P} 11, \mathrm{P} 35^{\mathrm{T}}$ and $\mathrm{P} 39$ are typical of other Geobacter species (Lovley et al., 2004).

Strains P11, P35 ${ }^{\mathrm{T}}$ and $\mathrm{P} 39$ were tested for salt tolerance, because $\mathrm{NaCl}$, in the form of road salt, periodically impacts
Table 2. Growth of strains $\mathrm{Bem}^{\top}, \mathrm{P} 11, \mathrm{P} 35^{\top}$ and $\mathrm{P} 39$, Geobacter chapellei $172^{\top}$ and Geobacter bremensis Dfr $1^{\top}$ on various electron acceptors

Acetate $(10 \mathrm{mM})$ was provided as the electron donor. Data for reference species were taken from Coates et al. (1996, 2001) (Geobacter chapellei $172^{\mathrm{T}}$ ) and from Straub et al. (1998) and Straub \& Buchholz-Cleven (2001) (Geobacter bremensis Dfr $1^{\mathrm{T}}$ ). NT, Not tested. Fumarate $(40 \mathrm{mM})$ and iron(III) oxide $(100 \mathrm{mM})$ tested positive for all strains shown; nitrate $(5 \mathrm{mM})$, sulfate $(10 \mathrm{mM})$ and thiosulfate $(10 \mathrm{mM})$ tested negative for all strains shown.

\begin{tabular}{|c|c|c|c|c|c|c|}
\hline Acceptor & Bem $^{T}$ & P11 & $\mathrm{P} 35^{\mathrm{T}}$ & P39 & $172^{\mathrm{T}}$ & Dfri $1^{T}$ \\
\hline AQDS (5 mM) & + & + & + & - & + & NT \\
\hline Elemental sulfur $\left(20 \mathrm{~g} \mathrm{l}^{-1}\right)$ & - & - & - & - & NT & + \\
\hline Graphite electrode & - & NT & + & NT & NT & NT \\
\hline Iron(III) citrate $(55 \mathrm{mM})$ & + & - & + & + & - & NT \\
\hline $\begin{array}{l}\text { Iron(III) pyrophosphate } \\
(10 \mathrm{mM})\end{array}$ & + & + & + & + & NT & NT \\
\hline Iron(III) NTA (5 mM) & + & + & + & + & + & NT \\
\hline Malate $(10 \mathrm{mM})$ & + & + & + & + & - & + \\
\hline $\begin{array}{l}\text { Manganese(IV) oxide } \\
\left(20 \mathrm{~g} \mathrm{l}^{-1}\right)\end{array}$ & + & - & + & + & + & + \\
\hline
\end{tabular}

the sediment from which the strains were isolated. Strains $\mathrm{P} 11, \mathrm{P} 35^{\mathrm{T}}$ and $\mathrm{P} 39$ were capable of growth and production of magnetite in the presence of $10 \mathrm{~g} \mathrm{NaCl}^{-1}$. Additionally, they were tolerant of 10,20 and $30 \mathrm{~g} \mathrm{NaCl}^{-1}$.

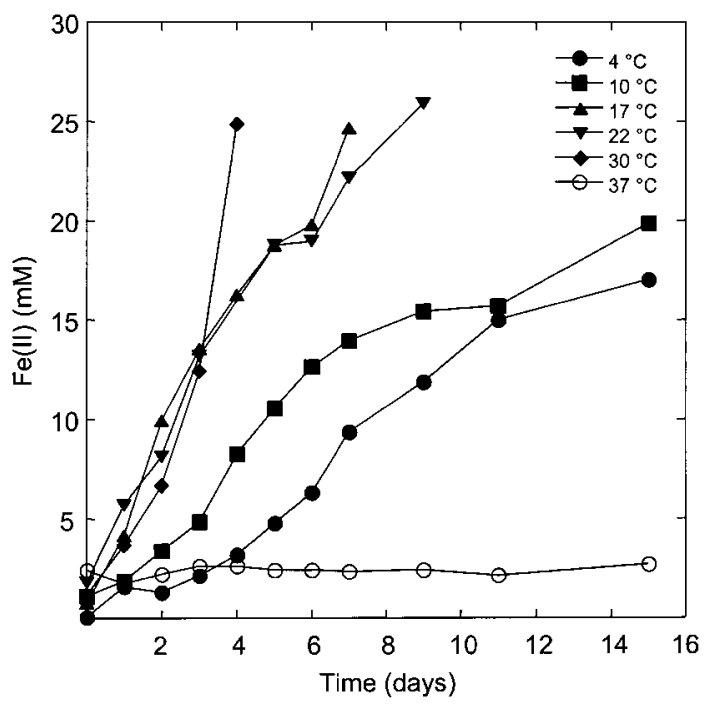

Fig. 2. Effect of temperature on the growth rate of strain $P 35^{\top}$. Cells were grown in medium with iron(III) oxide $\left(100 \mathrm{mmol}^{-1}\right)$ provided as the electron acceptor and acetate $(5 \mathrm{mM})$ as the electron donor. Data presented are means of triplicate incubations. 


\section{Cytochrome content, $\mathrm{G}+\mathrm{C}$ content and DNA-DNA hybridization}

The dithionite-reduced minus air-oxidized difference spectrum of all tested Geobacter species had peaks consistent with the presence of $c$-type cytochromes. Strain Bem $^{\mathrm{T}}$ had absorbance peaks at 422 and $555 \mathrm{~nm}$ and a shoulder at $522 \mathrm{~nm}$. Strain P11 had absorbance peaks at 420 and $551 \mathrm{~nm}$ and a shoulder at $521 \mathrm{~nm}$. Strain P $35^{\mathrm{T}}$ had absorbance peaks at 420 and $551 \mathrm{~nm}$ and a shoulder at $521 \mathrm{~nm}$. Strain P39 had absorbance peaks at 420 and $554 \mathrm{~nm}$ and a shoulder at $526 \mathrm{~nm}$. A similar spectrum was obtained from the control, Geobacter metallireducens, with peaks at 420 and $552 \mathrm{~nm}$ and a shoulder at $526 \mathrm{~nm}$.

The $\mathrm{G}+\mathrm{C}$ content of strain $\mathrm{Bem}^{\mathrm{T}}$ was $60.9 \mathrm{~mol} \%$ and that of strain $\mathrm{P} 35^{\mathrm{T}}$ was $63.8 \mathrm{~mol} \%$. The $\mathrm{G}+\mathrm{C}$ contents of Geobacter chapellei $172^{\mathrm{T}}$, Geobacter pelophilus $\mathrm{Dfr} 2^{\mathrm{T}}$, Geobacter metallireducens GS-15 ${ }^{\mathrm{T}}$, Geobacter grbiciae TACP$2^{\mathrm{T}}$, Geobacter hydrogenophilus $\mathrm{H}-2^{\mathrm{T}}$ Geobacter bremensis $\mathrm{Dfr}^{\mathrm{T}}{ }^{\mathrm{T}}$ and Geobacter sulfurreducens $\mathrm{PCA}^{\mathrm{T}}$ are respectively $50 \cdot 2,53,56 \cdot 6,57 \cdot 4,58 \cdot 4,60$ and $60 \cdot 9 \mathrm{~mol} \%$ (Lovley et al., 1993; Straub et al., 1998; Coates et al., 2001; Methé et al., 2003).

DNA-DNA hybridization of Geobacter bremensis $\operatorname{Dfr}^{\mathrm{T}}$ and strain $\mathrm{Bem}^{\mathrm{T}}$ yielded a DNA-DNA relatedness value of $63.5 \%$ (repeated measurement $55 \cdot 8 \%$ ). Geobacter bremensis $\mathrm{Dfr} 1^{\mathrm{T}}$ and strain $\mathrm{Bem}^{\mathrm{T}}$ are not related at the species level when a threshold value of $70 \%$ DNA-DNA relatedness for definition of bacterial species is considered (Wayne et al., 1987).

\section{Phylogenetic analysis of strains $\mathrm{P}^{3} 5^{\top}$ and $\mathrm{Bem}^{\boldsymbol{\top}}$}

Strain $\mathrm{Bem}^{\mathrm{T}}$ was included in a comprehensive phylogenetic study of the Geobacteraceae (Holmes et al., 2004b). When the nucleotide and amino acid sequences from six conserved genes, $16 \mathrm{~S}$ rRNA, rpoB, recA, gyrB, fusA and nifD, from strain $B e m^{\mathrm{T}}$ were analysed, it was apparent that strain $\mathrm{Bem}^{\mathrm{T}}$ fell within the Geobacter clade of the family Geobacteraceae in the class 'Deltaproteobacteria'. According to 16S rRNA gene nucleotide and nifD amino acid sequence comparisons, strain Bem ${ }^{\mathrm{T}}$ was most similar to Geobacter bremensis $\mathrm{Dfr} 1^{\mathrm{T}}$ and 'Geobacter humireducens' (99 and 95\% identical; see Supplementary Table S1 available in IJSEM Online).

Phylogenetic analysis of the 16S rRNA gene from strains $\mathrm{P} 35^{\mathrm{T}}, \mathrm{P} 39$ and P11 also indicated that these organisms belong to the genus Geobacter within the family Geobacteraceae (Fig. 3). Phylogeny of the nifD gene supports the placement of these strains as members of Geobacter (Fig. 3). The 16S rRNA nucleotide and nifD amino acid sequences from strain $\mathrm{P} 35^{\mathrm{T}}$ were most similar to those of G. chapellei $172^{\mathrm{T}}$ (96 and $82 \%$ identical; Supplementary Table S1).

\section{Description of Geobacter bemidjiensis sp. nov.}

Geobacter bemidjiensis (be.mid.ji.en'sis. N.L. masc. adj. bemidjiensis from Bemidji, MN, USA, where (a)

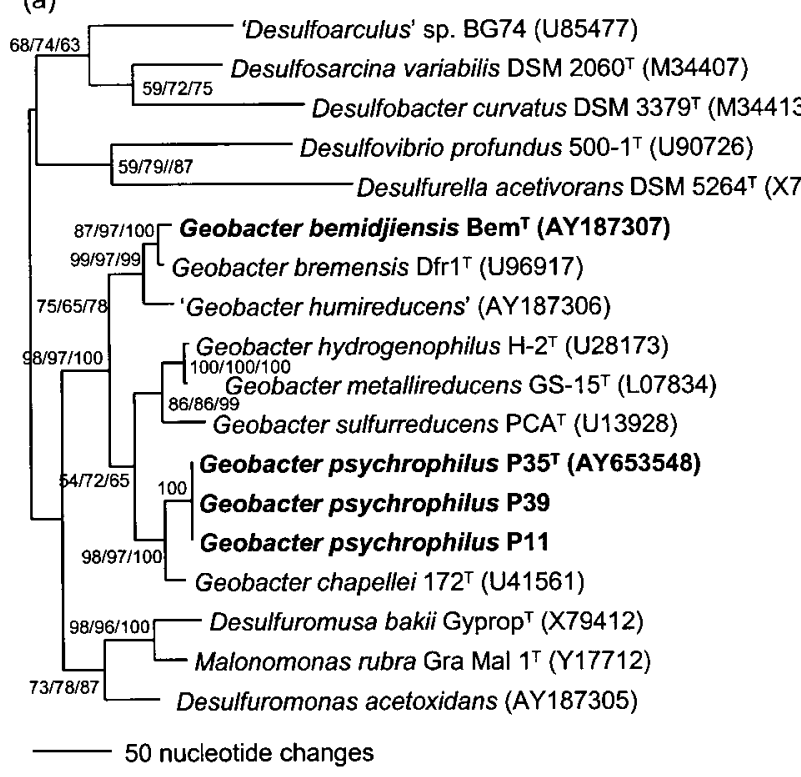

\section{(b)}

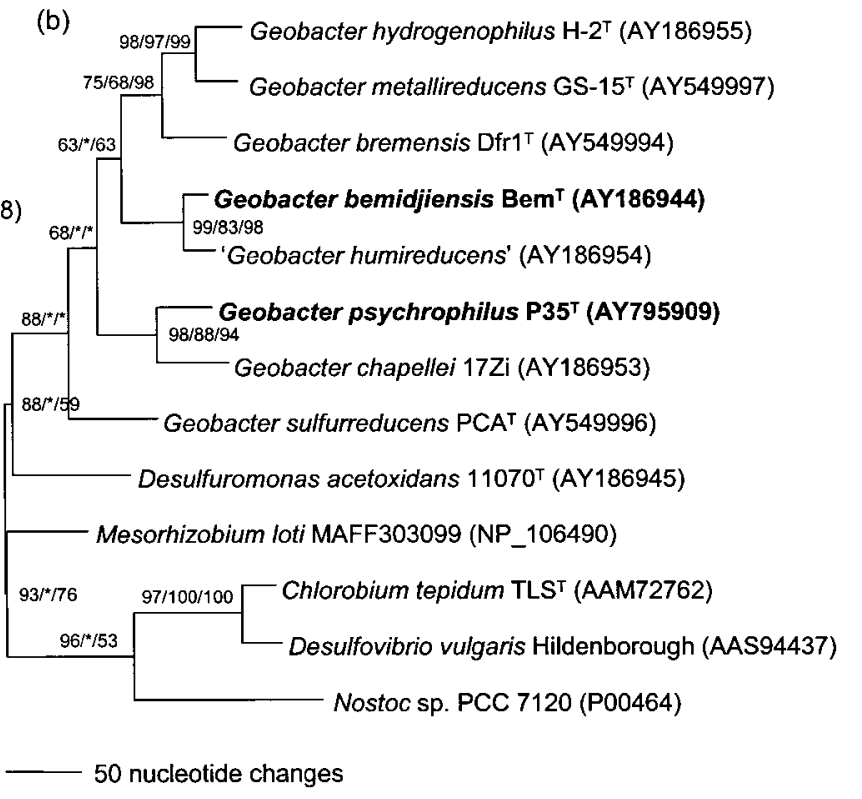

Fig. 3. Phylogenetic trees comparing $16 \mathrm{~S}$ rRNA gene sequences (a) and nifD sequences (b) from species of the Geobacteraceae. 'Desulfoarculus' sp. BG74, Desulfosarcina variabilis, Desulfobacter curvatus, Desulfovibrio profundus and Desulfurella acetivorans served as outgroups for construction of the 16S rRNA gene tree, while Desulfovibrio vulgaris, Mesorhizobium loti, Chlorobium tepidum and Nostoc sp. PCC 7120 were outgroups for the nifD tree. Bootstrap values obtained from 100 replicates by maximumparsimony/maximum-likelihood/distance-based analyses are shown; asterisks indicate values below 50 . 
sediment samples were taken from which the type strain was isolated).

Non-motile, Gram-negative, curved rods, approximately $2 \cdot 5-4 \mu \mathrm{m}$ in length and $0.5 \mu \mathrm{m}$ in diameter. Can couple the reduction of $\mathrm{Fe}$ (III) to the oxidation of acetate, benzoate, butanol, butyrate, ethanol, hydrogen, isobutyrate, malate, lactate, propionate, pyruvate, succinate and valerate. No growth when acetoin, arginine, benzaldehyde, benzyl alcohol, caproate, Casamino acids, ferulate, fructose, formate, gallic acid, glucose, glycerol, glutamine, isopropanol, mannitol, methanol, naphthalene, nicotinate, $o$-hydroxybenzoate, $p$-hydroxybenzaldehyde, $p$-hydroxybenzoate, $p$-hydroxybenzyl alcohol, phenol, proline, salicylic acid, serine, syringate, tryptone, toluene or yeast extract is provided as the electron donor. This species can utilize $\mathrm{Fe}(\mathrm{III})$, fumarate, AQDS, malate and manganese(IV) oxide as electron acceptors. No growth when elemental sulfur, nitrate, sulfate, thiosulfate or a graphite electrode is provided as the electron acceptor. Growth occurs at temperatures between 15 and $37^{\circ} \mathrm{C}$ (optimum temperature is approximately $30^{\circ} \mathrm{C}$ ). $c$-Type cytochromes are abundant. The $\mathrm{G}+\mathrm{C}$ content of the DNA is $60 \cdot 9 \mathrm{~mol} \%$.

The type strain is strain Bem $^{\mathrm{T}}$ ( = ATCC BAA- $1014^{\mathrm{T}}=$ DSM $16622^{\mathrm{T}}=\mathrm{JCM} 12645^{\mathrm{T}}$ ). The 16S rRNA (AY187307), gyrB (AY547335), fusA (AY188890), nifD (AY186994), rpoB (AY186914) and recA (AY186883) gene sequences of the type strain have been deposited in GenBank.

\section{Description of Geobacter psychrophilus sp. nov.}

Geobacter psychrophilus (psy.chro'phil.us. Gr. adj. psychros cold; Gr. adj. philos liking, loving; N.L. masc. adj. psychrophilus cold-loving).

Motile (monotrichous flagella), Gram-negative curved rods, approximately $2 \cdot 5-3 \mu \mathrm{m}$ in length and $0 \cdot 8 \mu \mathrm{m}$ in diameter. Can couple the reduction of $\mathrm{Fe}$ (III) to the oxidation of acetate, butanol, ethanol, formate, lactate, malate, pyruvate and succinate as the electron donor. No growth when acetoin, arginine, benzoate, butyrate, caproate, Casamino acids, ferulate, fructose, gallic acid, glycerol, hydrogen, isobutyrate, mannitol, nicotinate, proline, propionate, serine, syringate, tryptone, valerate or yeast extract is provided as electron donor. This species can utilize AQDS, iron(III) citrate, iron(III) oxide, iron(III) pyrophosphate, iron(III) NTA, fumarate, malate, manganese(IV) oxide and graphite electrodes as electron acceptors. No growth when elemental sulfur, nitrate, sulfate or thiosulfate is provided as electron acceptor. Growth occurs at temperatures between 4 and $30{ }^{\circ} \mathrm{C}$ (optimum temperature range is $17-30^{\circ} \mathrm{C}$ ). $c$-Type cytochromes are abundant. The $\mathrm{G}+\mathrm{C}$ content of the DNA of the type strain is $63 \cdot 8 \mathrm{~mol} \%$.

The type strain is strain P35 $5^{\mathrm{T}}$ ( = ATCC BAA- $1013^{\mathrm{T}}=\mathrm{DSM}$ $16674^{\mathrm{T}}=\mathrm{JCM} 12644^{\mathrm{T}}$ ). The 16S rRNA (AY653548), fusA
(AY653550) and nifD (AY795909) gene sequences have been deposited in GenBank.

\section{ACKNOWLEDGEMENTS}

We would like to thank Dale Callaham of the University of Massachusetts Amherst Microscopy facility for SEM/TEM. This research was supported by Massachusetts Highway Department ISA 9775 and the Office of Science (BER), US Department of Energy, Cooperative Agreement no. DE-FC02-02ER63446 and grant no. DEFG02-97ER62475. The authors acknowledge and appreciate the logistical and sampling support provided by District 5 of MassHighway. The views, opinions and findings contained in this paper are those of the authors and do not necessarily reflect MassHighway official views or policies. This paper does not constitute a standard, specification or regulation.

\section{REFERENCES}

Achenbach, L. \& Woese, C. (1995). $16 \mathrm{~S}$ and $23 \mathrm{~S}$ rRNA-like primers. In Archaea: a Laboratory Manual, pp. 201-203. Edited by F. T. Robb, A. R. Place, K. R. Sowers and others. Cold Spring Harbor, NY: Cold Spring Harbor Laboratory.

Altschul, S. F., Gish, W., Miller, W., Myers, E. W. \& Lipman, D. J. (1990). Basic local alignment search tool. J Mol Biol 215, 403-410.

Amann, R. I., Binder, B. J., Olson, R. J., Chisholm, S. W., Devereux, R. \& Stahl, D. A. (1990). Combination of $16 \mathrm{~S}$ rRNA-targeted oligonucleotide probes with flow cytometry for analyzing mixed microbial populations. Appl Environ Microbiol 56, 1919-1925.

Anderson, R. T. \& Lovley, D. R. (1999). Naphthalene and benzene degradation under $\mathrm{Fe}(\mathrm{III})$-reducing conditions in petroleumcontaminated aquifers. Bioremediation J 3, 121-135.

Anderson, R. T. \& Lovley, D. R. (2000). Anaerobic bioremediation of benzene under sulfate-reducing conditions in a petroleumcontaminated aquifer. Environ Sci Technol 34, 2261-2266.

Anderson, R. T., Vrionis, H. A., Ortiz-Bernad, I. \& 10 other authors (2003). Stimulated in situ activity of Geobacter species to remove uranium from the groundwater of a uranium-contaminated aquifer. Appl Environ Microbiol 69, 5884-5891.

Bazylinski, D. A., Dean, A. J., Schuler, D., Phillips, E. J. P. \& Lovley, D. R. (2000). $\mathrm{N}_{2}$-dependent growth and nitrogenase activity in the metal-metabolizing bacteria, Geobacter and Magnetospirillum species. Environ Microbiol 2, 266-273.

Bond, D. R. \& Lovley, D. R. (2003). Electricity production by Geobacter sulfurreducens attached to electrodes. Appl Environ Microbiol 69, 1548-1555.

Bond, D. R., Holmes, D. E., Tender, L. M. \& Lovley, D. R. (2002). Electrode-reducing microorganisms that harvest energy from marine sediments. Science 295, 483-485.

Bowman, J. P., McCammon, S. A., Nichols, D. S., Skerratt, J. H., Rea, S. M., Nichols, D. S. \& McMeekin, T. A. (1997). Shewanella gelidimarina sp. nov. and Shewanella frigidimarina sp. nov., novel Antarctic species with the ability to produce eicosapentaenoic acid $(20: 5 \omega 3)$ and grow anaerobically by dissimilatory $\mathrm{Fe}(\mathrm{III})$ reduction. Int J Syst Bacteriol 47, 1040-1047.

Bozal, N., Montes, M. J., Tudela, E., Jimenez, F. \& Guinea, J. (2002). Shewanella frigidimarina and Shewanella livingstonensis sp. nov. isolated from Antarctic coastal areas. Int J Syst Evol Microbiol 52, 195-205.

Caccavo, F., Jr, Lonergan, D. J., Lovley, D. R., Davis, M., Stolz, J. F. \& McInerney, M. J. (1994). Geobacter sulfurreducens sp. nov., a 
hydrogen- and acetate-oxidizing dissimilatory metal-reducing microorganism. Appl Environ Microbiol 60, 3752-3759.

Cashion, P., Holder-Franklin, M. A., McCully, J. \& Franklin, M. (1977). A rapid method for the base ratio determination of bacterial DNA. Anal Biochem 81, 461-466.

Childers, S. E., Ciufo, S. \& Lovley, D. R. (2002). Geobacter metallireducens accesses insoluble $\mathrm{Fe}(\mathrm{III})$ oxide by chemotaxis. Nature 416, 767-769.

Church, P., Armstrong, D., Granato, G., Stone, V., Smith, K. \& Provencher, P. (1996). Effectiveness of highway-drainage systems in preventing contamination of ground water by road salt, Route 25, Southeastern Massachusetts - Description of study area, data collection programs, and methodology. US Geological Survey, Open-file report 96-317.

Coates, J. D., Phillips, E. J., Lonergan, D. J., Jenter, H. \& Lovley, D. R. (1996). Isolation of Geobacter species from diverse sedimentary environments. Appl Environ Microbiol 62, 1531-1536.

Coates, J. D., Bhupathiraju, V. K., Achenbach, L. A., McInerney, M. J. \& Lovley, D. R. (2001). Geobacter hydrogenophilus, Geobacter chapellei and Geobacter grbiciae, three new, strictly anaerobic, dissimilatory Fe(III)-reducers. Int J Syst Evol Microbiol 51, 581-588.

Coppi, M. V., Leang, C., Sandler, S. J. \& Lovley, D. R. (2001). Development of a genetic system for Geobacter sulfurreducens. Appl Environ Microbiol 67, 3180-3187.

Cummings, D. E., Snoeyenbos-West, O. L., Newby, D. T., Niggemyer, A. M., Lovley, D. R., Achenbach, L. A. \& Rosenzweig, R. F. (2003). Diversity of Geobacteraceae species inhabiting metalpolluted freshwater lake sediments ascertained by $16 \mathrm{~S}$ rDNA analyses. Microb Ecol 46, 257-269.

De Ley, J., Cattoir, H. \& Reynaerts, A. (1970). The quantitative measurement of DNA hybridization from renaturation rates. Eur J Biochem 12, 133-142.

Eden, P. A., Schmidt, T. M., Blakemore, R. P. \& Pace, N. R. (1991). Phylogenetic analysis of Aquaspirillum magnetotacticum using polymerase chain reaction-amplified $16 \mathrm{~S}$ rRNA-specific DNA. Int J Syst Bacteriol 41, 324-325.

Finneran, K., Johnsen, C. V. \& Lovley, D. R. (2003). Rhodoferax ferrireducens sp. nov., a psychrotolerant, facultatively anaerobic bacterium that oxidizes acetate with the reduction of $\mathrm{Fe}(\mathrm{III})$. Int J Syst Evol Microbiol 53, 669-673.

Helms, A. C., Martiny, A. C., Hofman-Bang, J., Ahring, B. K. \& Kilstrup, M. (2004). Identification of bacterial cultures from archaeological wood using molecular biological techniques. Int Biodeterior Biodegrad 53, 79-88.

Holmes, D. E., Bond, D. R., O'Neil, R. A., Reimers, C. E., Tender, L. R. \& Lovley, D. R. (2004a). Microbial communities associated with electrodes harvesting electricity from a variety of aquatic sediments. Microb Ecol 48, 178-190.

Holmes, D. E., Nevin, K. P. \& Lovley, D. R. (2004b). Comparison of $16 \mathrm{~S}$ rRNA, nifD, recA, gyrB, rpoB and fusA genes within the family Geobacteraceae fam. nov. Int $J$ Syst Evol Microbiol 54, 1591-1599.

Holmes, D. E., Nicoll, J. S., Bond, D. R. \& Lovley, D. R. (2004c). Potential role of a novel psychrotolerant member of the Geobacteraceae, Geopsychrobacter electrodiphilus gen. nov., sp. nov., in electricity production by the marine sediment fuel cell. Appl Environ Microbiol 70, 6023-6030.

Huß, V. A. R., Festl, H. \& Schleifer, K. H. (1983). Studies on the spectrophotometric determination of DNA hybridization from renaturation rates. Syst Appl Microbiol 4, 184-192.

Ikenaga, M., Asakawa, S., Muraoka, Y. \& Kimura, M. (2003). Bacterial communities associated with nodal roots of rice plants along with the growth stages: estimation by PCR-DGGE and sequence analyses. Soil Sci Plant Nutr 49, 591-602.

Istok, J. D., Senko, J. M., Krumholz, L. R., Watson, D., Bogle, M. A., Peacock, A., Chang, Y.-J. \& White, D. C. (2004). In situ bioreduction of technetium and uranium in a nitrate-contaminated aquifer. Environ Sci Technol 38, 468-475.

Kashefi, K. \& Lovley, D. (2003). Extending the upper temperature limit for life. Science 301, 934.

Kashefi, K., Holmes, D. E., Lovley, D. R. \& Tor, J. (2004). Potential importance of dissimilatory $\mathrm{Fe}$ (III)-reducing microorganisms in hot sedimentary environments. In The Subseafloor Biosphere at Mid-Ocean Ridges, Geophysical Monograph Series no. 144, pp. 199-211. Washington, DC: American Geophysical Union Press.

Knoblauch, C., Sahm, K. \& Jorgensen, B. B. (1999). Psychrophilic sulfate-reducing bacteria isolated from permanently cold Arctic marine sediments: description of Desulfofrigus oceanense gen. nov., sp. nov., Desulfofrigus fragile sp. nov., Desulfofaba gelida gen. nov., sp. nov., Desulfotalea psychrophila gen. nov., sp. nov. and Desulfotalea arctica sp. nov. Int J Syst Bacteriol 49, 1631-1643.

Leonardo, M. R., Moser, D. P., Barbieri, E., Brantner, C. A., MacGregor, B. J., Paster, B. J., Stackebrandt, E. \& Nealson, K. H. (1999). Shewanella pealeana sp. nov., a member of the microbial community associated with the accessory nidamental gland of the squid Loligo pealei. Int J Syst Bacteriol 49, 1341-1351.

Lovley, D. R. (1991). Dissimilatory $\mathrm{Fe}(\mathrm{III})$ and $\mathrm{Mn}(\mathrm{IV})$ reduction. Microbiol Rev 55, 259-287.

Lovley, D. (2000). Fe(III) and Mn(IV)-reducing prokaryotes. In The Prokaryotes, 3rd edn. Edited by M. Dworkin, S. Falkow, E. Rosenberg, K. H. Schleifer \& E. Stackebrandt. New York: Springer.

Lovley, D. (2005). Fe(III)- and Mn(IV)-reducing prokaryotes. In The Prokaryotes, 4th edn. Edited by M. Dworkin, S. Falkow, E. Rosenberg \& M. Fletcher. New York: Springer (in press).

Lovley, D. R. \& Chapelle, F. H. (1995). Deep subsurface microbial processes. Rev Geophys 33, 365-381.

Lovley, D. R. \& Phillips, E. J. P. (1986). Availability of ferric iron for microbial reduction in bottom sediments of the freshwater tidal Potomac River. Appl Environ Microbiol 52, 751-757.

Lovley, D. R. \& Phillips, E. J. P. (1987). Rapid assay for microbially reducible ferric iron in aquatic sediments. Appl Environ Microbiol 53, 1536-1540.

Lovley, D. R. \& Phillips, E. J. P. (1988). Novel mode of microbial energy metabolism: organic carbon oxidation coupled to dissimilatory reduction of iron or manganese. Appl Environ Microbiol 54, 1472-1480.

Lovley, D. R., Stolz, J. F., Nord, G. L. \& Phillips, E. J. P. (1987). Anaerobic production of magnetite by a dissimilatory iron-reducing microorganism. Nature 330, 252-254.

Lovley, D. R., Giovannoni, S. J., White, D. C., Champine, J. E., Phillips, E. J. P., Gorby, Y. A. \& Goodwin, S. (1993). Geobacter metallireducens gen. nov. sp. nov., a microorganism capable of coupling the complete oxidation of organic compounds to the reduction of iron and other metals. Arch Microbiol 159, 336-344.

Lovley, D. R., Holmes, D. E. \& Nevin, K. P. (2004). Dissimilatory $\mathrm{Fe}(\mathrm{III})$ and $\mathrm{Mn}(\mathrm{IV})$ reduction. Adv Microb Physiol 49, 219-286.

Maidak, B. L., Cole, J. R., Lilburn, T. G. \& 7 other authors (2001). The RDP-II (Ribosomal Database Project). Nucleic Acids Res 29, 173-174.

Methé, B. A., Nelson, K. E., Eisen, J. A. \& 31 other authors (2003). Genome of Geobacter sulfurreducens: metal reduction in subsurface environments. Science 302, 1967-1969. 
Nevin, K. P. \& Lovley, D. R. (2000a). Lack of production of electronshuttling compounds or solubilization of $\mathrm{Fe}$ (III) during reduction of insoluble $\mathrm{Fe}(\mathrm{III})$ oxide by Geobacter metallireducens. Appl Environ Microbiol 66, 2248-2251.

Nevin, K. P. \& Lovley, D. R. (2000b). Potential for nonenzymatic reduction of $\mathrm{Fe}(\mathrm{III})$ via electron shuttling in subsurface sediments. Environ Sci Technol 34, 2472-2478.

Nevin, K. \& Lovley, D. (2002a). Mechanisms for Fe(III) oxide reduction in sedimentary environments. Geomicrobiol J 19, 141-159.

Nevin, K. P. \& Lovley, D. R. (2002b). Mechanisms for accessing insoluble $\mathrm{Fe}(\mathrm{III})$ oxide during dissimilatory $\mathrm{Fe}(\mathrm{III})$ reduction by Geothrix fermentans. Appl Environ Microbiol 68, 2294-2299.

Ostendorf, D. (1997-2004). Highway deicing agent impacts on soil and groundwater quality. Series of Monthly Progress Reports. Prepared under ISA and ISA 9775 for the Massachusetts Highway Department.

Pearson, W. R. (1990). Rapid and sensitive sequence comparison with FASTP and FASTA. Methods Enzymol 183, 63-98.

Petrie, L., North, N. N., Dollhopf, S. F., Balkwill, D. L. \& Kostka, J. E. (2003). Enumeration and characterization of iron(III)-reducing microbial communities from acidic subsurface sediments contaminated with uranium(VI). Appl Environ Microbiol 69, 7467-7479.

Roling, W. F. M., van Breukelen, B. M., Braster, M., Lin, B. \& van Verseveld, H. W. (2001). Relationships between microbial community structure and hydrochemistry in a landfill leachate-polluted aquifer. Appl Environ Microbiol 67, 4619-4629.

Rooney-Varga, J. N., Anderson, R. T., Fraga, J. L., Ringelberg, D. \& Lovley, D. R. (1999). Microbial communities associated with anaerobic benzene degradation in a petroleum-contaminated aquifer. Appl Environ Microbiol 65, 3056-3063.

Snoeyenbos-West, O. L., Nevin, K. P., Anderson, R. T. \& Lovley, D. R. (2000). Enrichment of Geobacter species in response to stimulation of $\mathrm{Fe}$ (III) reduction in sandy aquifer sediments. Microb Ecol 39, 153-167.
Stein, L. Y., La Duc, M. T., Grundl, T. J. \& Nealson, K. H. (2001). Bacterial and archaeal populations associated with freshwater ferromanganous micronodules and sediments. Environ Microbiol 3, $10-18$.

Straub, K. L. \& Buchholz-Cleven, B. E. E. (2001). Geobacter bremensis sp. nov. and Geobacter pelophilus sp. nov., two dissimilatory ferric-iron-reducing bacteria. Int J Syst Evol Microbiol 51, 1805-1808.

Straub, K. L., Hanzlik, M. \& Buchholz-Cleven, B. E. E. (1998). The use of biologically produced ferrihydrite for the isolation of novel iron-reducing bacteria. Syst Appl Microbiol 21, 442-449.

Swofford, D. (1998). PAUP - Phylogenetic Analysis Using Parsimony ( ${ }^{*}$ and other methods), version 4 . Sunderland, MA: Sinauer Associates.

Thompson, J. D., Gibson, T. J., Plewniak, F., Jeanmougin, F. \& Higgins, D. G. (1997). The CLUSTAL_X Windows interface: flexible strategies for multiple sequence alignment aided by quality analysis tools. Nucleic Acids Res 25, 4876-4882.

Ueda, T., Suga, Y., Yahiro, N. \& Matsuguchi, T. (1995). Genetic diversity of $\mathrm{N}_{2}$-fixing bacteria associated with rice roots by molecular evolutionary analysis of a nifD library. Can J Microbiol 41, 235-240.

Vargas, M., Kashefi, K., Blunt-Harris, E. L. \& Lovley, D. R. (1998). Microbiological evidence for $\mathrm{Fe}(\mathrm{III})$ reduction on early Earth. Nature 395, 65-67.

Vrionis, H. A., Anderson, R. T., Ortiz-Bernad, I., O'Neill, K. R., Resch, C. T., Long, P. E. \& Lovley, D. R. (2005). Shifts in geochemistry and microbial community distributions in response to biostimulation in a uranium-contaminated aquifer. Appl Environ Microbiol (in press).

Wayne, L. G., Brenner, D. J., Colwell, R. R. \& 9 other authors (1987) Report of the ad hoc committee on reconciliation of approaches to bacterial systematics. Int J Syst Bacteriol 37, 463-464. 